\title{
Overconsumption in Ethic Economics and Sustainable Development
}

\author{
Bijan Bidabad \\ B.A., M.Sc., Ph.D., Post-Doc. \\ Professor \\ Economics and Chief Islamic Banking Advisor \\ Bank Melli, Iran \\ E-mail:bijan@bidabad.com
}

\begin{abstract}
Squandering or spending more than need, which is a concept in ethic economics, which has been reconsidered under the subject of sustainable development at the present time. It is shown on the whole that the increase of per-capita consumption, the effects on the environment will increase; in other words, the environmental carrying capacity will decrease. At present world conditions, squandering means aggression to others' rights and in addition to be disagreeable, but by compiling rules, it can be regarded in the domain of offense and crime at national and global levels. This is because squanderer endangers the environment and interests of others for her own benefit.As a model to use resources to serve human being needs for present and coming generations, sustainable development is put forward, which coincides with disagreeability of squandering in ethic economics. In spite of considering the sustainability of the environment, this concept takes into account the areas such as economics, sociopolitics, and variety of cultural and life realms regarding intellectualism, sentiments, ethical and spiritual subjects. Regarding the chain of production, it also points to squandering as a topic in industrial ecology. Industrial ecology recommends converting industrial production processes from linear to circular systems in which, scraps and wastes are recycled as factors of other productions. Clean technology and its related regulations and cleaner production are also related to squandering concept in production.
\end{abstract}

Keywords: Sustainable development, Overconsumption, Ethic economics, Squandering

\section{Introduction}

Many of the discussions which are headlines of strategic policies today, had been under consideration at the thousands of years before, and divine theosophists have explained these teachings. Sustainable development discussion which is one of the raised problems at international societies, and has been put forward in theoretical and modern form in the $20^{\text {th }}$ century, is in the domain of ethic economics and this classical concept has not been considered much. Squandering, with the meaning of excessive consumption, is one of the ethic economics topics. Generally, this concept is coinciding with extravagance and consumptionism at the national level, but its application at international level and global economy bring this concept to mind which can be clearly understood by this example': If animals were intelligent, they practiced a better life. In this connection, when microbes enter our body, they live in it, as we live on the earth and eat from our body, which is similar to earth for them. The coexistence of many bacteria and microbes with human beings' bodies is a proved medical proposition. The body tolerates them, and they nourish in the body and live together with a human being. That is to say, for example, many bacteria help in the digestive system to fermentation and digest food, and health and even the life of human beings depend on their existence. But the microbes and bacteria overdo their works so that the body dies, and they die too. Their actions are similar to our actions. We say other creatures are not intellectuals, but we who are intellectual, should not do things to ruin our lives. The masters have commanded in all these subjects: "eat and drink, but don't waste because God doesn't like squanderers..." which means human being enjoys so much from God's blessing so that he spoils his own life; that is why it is commanded not to squander...

A similar example is a misuse or wasteful use of earth by the human beings. Practically, excessive use of the earth will ruin it, and the result is the ruin of people living on it. This ethical comparison, which is in the domain of ethic economics, put forward at the end of the last century by economists and environmental and social experts and were considered as sustainable development

I - Speech of his Excellency Dr. hajj Nour-Ali Tabandeh Majzoubalishah, March 25 2008.

http://mazaresoltani.net/download/mp3/87/87-0I-25-sobhe-eshanbeh-aghl.mp3 
theory. Movements such as "Anti-consumption", "Ecological economics", "Green Economics", and "Freeganism" in recent decades are also along in this direction.

Ethic economics is a new name for the old value discussions in economics which analyze the economy and economic behaviors by observing ethical principles. The aim of economic researches in this direction is to consider materialistic economic problems as well as value-based principles of human ethics. This view to economic problems studies two materialistic and spiritual dimensions of human being in relation with economics simultaneously and takes the human behavior into account from these two views which in contrary to materialistic view, it has a wider view and in addition to observing economic scientific rules, tries to find material and spiritual welfare of human beings in a broader range than just materials.

\section{Sustainable development}

Sustainable development is a pattern of resource use that aims to meet the needs of the present without compromising the ability of future generations to meet their own needs ${ }^{2}$. That is to say, today's needs of the human beings should be met in a way that future generations would not suffer shortages.

Generally, sustainable development debates are about various areas in which sustainable consumption and production are the most important ${ }^{3}$. Sustainable production and consumption is the use of goods and services for essential needs and improvement of quality of life, and while the use of natural resources and poisonous materials and production of spoils and contaminating materials are minimized in the lifetime, they will not endanger the needs of next generations ${ }^{4}$. Sustainable production and consumption in economic activities include government, societies, and families so that they consider efficient production and natural resources use, to minimize spoils and wastes, and optimize production of goods and services ${ }^{5}$. Sustainable production emphasizes on demand side and improvement of the environmental performance of the main economic sectors such as agriculture, energy, industry, tourism, and transportation. Sustainable consumption refers to the demand side and the method of using goods and services to meet the main needs and improve the quality of life. In other words, food and health care, shelter, clothing, leisure and work should be changed so that they decrease pressure on earth carrying capacity ${ }^{6}$. While sustainable consumption means the improvement of the quality of consumption for present and future generations. This concept of consumption needs optimization of consumption by considering the preservation of services and quality of resources and environment along the time ${ }^{7}$.

Sustainable development consists of three main parts of the sustainability of environment, economy, and socio-politics. Generalization of sustainable development to these dimensions has been decided in the World Health Organization in $2005^{8}$. The United Nations 2005 World Summit Outcome Document refers to the "interdependent and mutually reinforcing pillars" of sustainable development as economic development, social development, and environmental protection. The Universal Declaration on Cultural Diversity (UNESCO, 200I) has brought the concept of sustainable development to the cultural domain. It is said in this declaration: "the same as the diversity of life which is necessary for nature, cultural diversity is also necessary for the human being". In completing the definition of sustainable development, the declaration makes it clear that: "among development pillars, economic growth is not enough, but the methods of obtaining more satisfactory life in the fields of intellectualism, sentiments, ethical and spiritual are also important”.

More generally, $\mathrm{Hansa}^{9}$ believes that sustainable development is a process which covers all directions of human life affecting his livelihood. The meaning of "Green development" is quite different from sustainable development. Those who are in favor of

\footnotetext{
2 - Report of the world commission on environment and development, United Nations General Assembly Resolution 42/I87, II December 1987, retrieved: 2007-04-I2.

3 - http://www.iisd.org/susprod/principles.htm

4 - Symposium: Sustainable Consumption. Oslo, Norway; 19-20 January I994.

5 - Edwin G. Falkman, Waste Management International. Sustainable Production and Consumption: A Business Perspective. WBCSD, n.d.

${ }^{6}$ - Nick Robins, Sarah Roberts, Changing Consumption and Production Patterns: Unlocking Trade Opportunities. International Institute for Environment and Development and UN Department of Policy Coordination and Sustainable Development, 1997.

7 - Emil Salim, The challenge of sustainable consumption as seen from the South. In Symposium: Sustainable Consumption. Oslo, Norway; 19-20 January 1994.

8 - Word summit outcome document, World Health Organization, I September 2005.

9 - Hasna, A.M., 2007, Dimensions of sustainability, Journal of Engineering for Sustainable Development: Energy Environment and Health 2 (I):47-57 retrieved on 2008-04-20. 
green development prefer sustainability of environment to economic, social, and cultural considerations which are unidirectional consideration of the sustainable development goal along with the future life of the earth planet. Anyhow, in spite of views of various schools of thoughts ${ }^{10}$ about sustainable development, especially in relationship with "Anthropocentrism", and "Ecocentrism", United Nations Division for Sustainable Development ${ }^{\mathrm{II}}$ has considered the following fields in the domain of sustainable development:

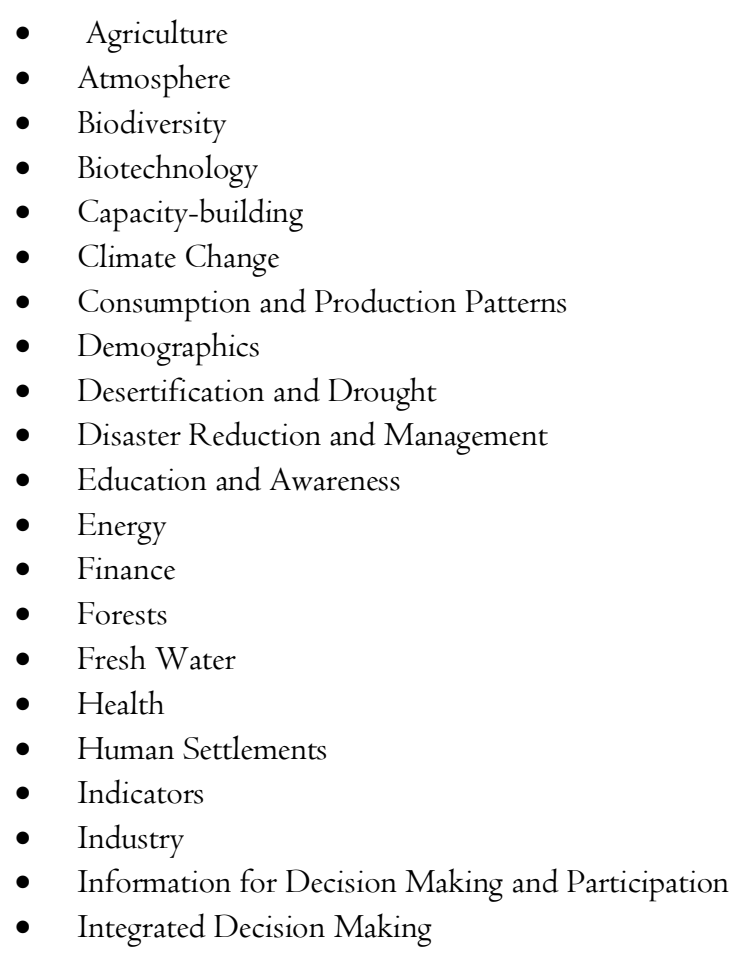

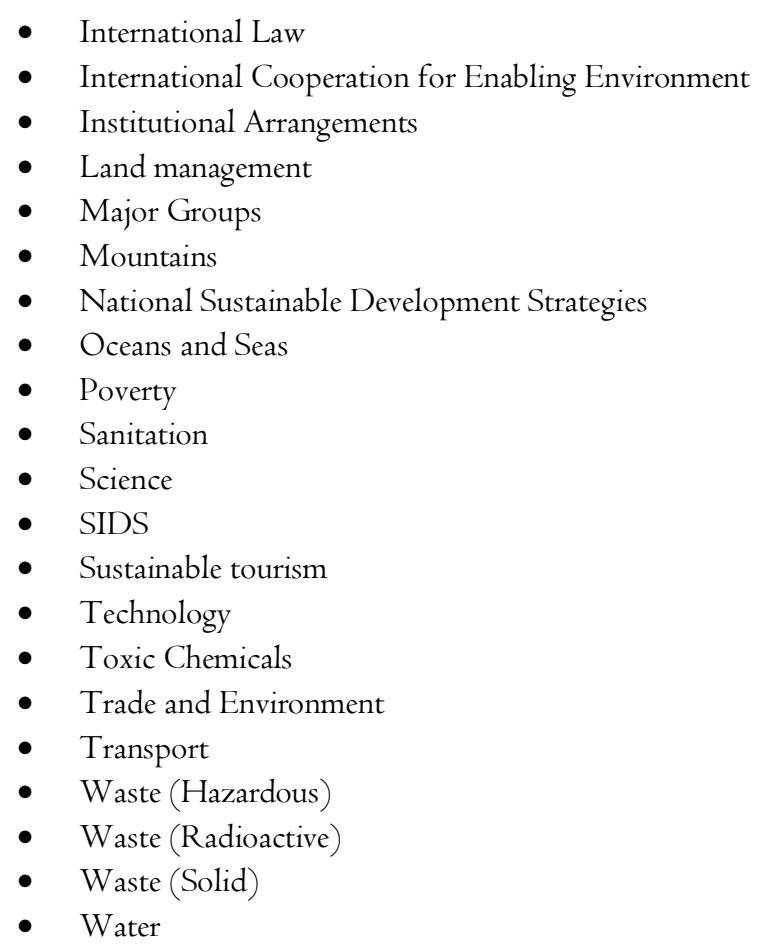

During the last decade, various organizations have tried to introduce measures for monitoring sustainability under the names of metrics and sustainability indices. Many believe that the concepts of sustainable development are against growth and even implementing sustainable development principles will return human being to the living methods of previous eras ${ }^{12}$.

\section{Carrying capacity}

One of the problems in the relationship with sustainable development is the carrying capacity of the earth. The carrying capacity of an ecosystem is equal with the number of people of an organism which can be served (protected) in the framework of the respected ecosystem from various views such as: food, housing, sunshine, air, and other needs. We should add other variables such as sewage, health care, and others for the human being. When the density of an ecosystem increases, usually birth rate decreases and the death rate of the respected organism will increase. The difference between these two rates is called "natural growth rate" for which the ecosystem carrying capacity should consider to support. Exceeding carrying capacity, ecosystem population will decrease, and below that, the population will increase ${ }^{\mathrm{I} 3}$. Of course, there are exceptions which are usually temporal. That is to say, the number of dwellers of a variety of living creatures may be more than carrying capacity, but this habitation is not enduring and will decrease after a while. This concept creates a regular rule for adjusting the growth rate of the resident number of the ecosystem, and the increase of one kind of creature may create problems which not only decreases the number of population of that kind but also changes the population of other kinds.

\footnotetext{
${ }^{10}$ - Center for Sustainable Global Enterprise, Cornell University. Erb Institute for Global Enterprise, University of Michigan.

${ }^{\text {II }}$ United Nations division for Sustainable Development. Documents: Sustainable Development Issues. Retrieved 2007-05-12.

I2 - Temple (1992) what is sustainable development?

13 - Sayre, N.F.2008, The genesis history, and limits of carrying capacity, Annals of the Association of American geographers, 98 (I), pp. I20134 .
} 
The famous Lotka-Volterra equation shows for some special kind of creatures how in the present condition of resources, the inhabiting population will face famine. The relationship of human being and environment is much more complicated, because, people always change the shapes of available resources and obtain scarce resources from plentiful resources, which cause population decrease and also by scientific methods decreases deaths. Anyhow, in spite of this, the simple equation of IPAT shows the carrying capacity:

$$
\mathrm{I}=\text { P.A.T. }
$$

Where:

$$
\begin{aligned}
& \mathrm{I}=\text { effects of consumption on the environment } \\
& \mathrm{P}=\text { number of creatures (people) } \\
& \mathrm{A}=\text { per-capita effects of consumption on the environment } \\
& \mathrm{T}=\text { technology factor }
\end{aligned}
$$

Although this equation has several strong assumptions, but shows, the increase of per-capita consumption will increase the effects on the environment and, in other words, will decrease the carrying capacity of the environment. Many sociologists and demographers from Malthus ${ }^{I 4}$ until present time have explained population growth as a fearful phenomenon. Even the Club of Rome $^{15}$ has forecasted this concept as an important danger for the $2 \mathrm{I}^{\text {st }}$ century ${ }^{\mathrm{I}}$, but many other scientists believe that by changing technology, people can increase the improvement of food production and carrying capacity of the earth. Including, we can mention theories of a Danish economist Ester Boserup ${ }^{17}$ which is known as "Adaptation process". This process from rationality view coincides with the narration of the Prophet Mohammad (peace be upon him) who emphasizes on the increase of human generation ${ }^{18}$. That is, in spite of Malthus, who is narrow-minded, because of the adaptation theory, the honorable Prophet, not only doesn't see any barriers for population increase, but also emphasizes on population increase. This is because the wise men borne will help each other to solve the problems. This is because each human being borne has an intellect which can solve the problem. But nevertheless, this does not deny squandering in ethic economics. We can easily understand from IPAT equation that in squandering conditions, the consumption effects (I) on the environment will aggravate because per-capita consumption (A) effect will also aggravate and thereof, will decrease the earth carrying capacity. In other words, in stationary adaptation conditions, ceteris paribus, that is, when the number of people $(\mathrm{P})$ and technology factor $(\mathrm{T})$ are unchanged, the increase of per-capita consumption (A) will proportionally increase the consumption effects (I) on the environment.

\section{Overconsumption in holly Quran}

Despite the generality of the word Squandering and verification of its generality on all human actions and behaviors, overconsumption has more particular economic meaning. Ragheb Esfahani ${ }^{-19}$ defines overconsumption (Tabzir) as spread out like sowing grains and concerns anybody who wastes his properties. Tabrasi ${ }^{20}$ translates overconsumption (Tabzir) as spreading out her properties by squandering and wasting it, but admits that in a righteousness manner with goodness goal, this action will not be classified as Tabzir. Quran says ${ }^{21}$ (17:26-27): "give to the near of kin, the needy and the destitute traveler their rights and do not squander (spread out), for the wasteful are the brothers of Satan; and Satan is ungrateful to his Lord." Interpretation of this verse in Bayanol Seada exegeses is as ${ }^{22}$ : the words squander (spread out) is allocated to the meaning of donation to whom is

I4 - Thomas Malthus (I798), An essay on the principle of population.

I5 - The Club of Rome, "Limits to growth" (1972).

${ }^{16}$ - Paul R. Ehrlich (1968), "Population bomb”.

${ }^{17}$ - Ester Boserup (1965), The conditions of agricultural growth, Allen Unwin. Revised and reprinted in population and technology, Blackwell 1980.

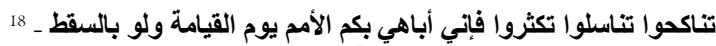

19 البذر تضييع فى الظاهر لمن لم يعرف مآل مايلقيه.

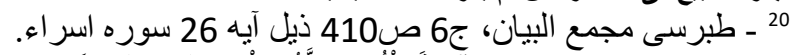

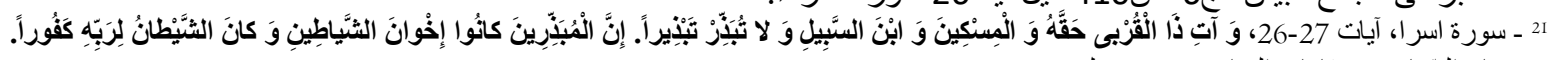

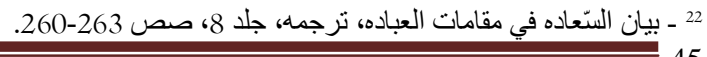


not the rightful receiver or if the gift is more than the proper right of the receiver, which is the meaning of squandering, and is prohibited by this verse. Because giving property without squandering is the true meaning of economy (moderation). So Tabzir or overconsumption is included in squandering subject, even if sometimes is placed against it. And as long as the command is for payment of the right implies avoiding of not-paying (avarice-greed), this led to suffice to just command to not-squander, because paying the right is not limited to just material properties and family and includes other rights and all members in internal and external worlds of the human being. It is narrated that the prophet passing beside Saad (an apostle) making ablution protested; "Saad what is this squandering? The apostle retorted: is there squandering making ablution (his religious duty of wash up for prayer). The prophet said yes, there is even if you are beside the full fountain. It is also narrated that Imam Sadiq in response to the question: "Is there also overconsumption on those that are permitted? Imam said yes and the mystery of it is the fact that anytime a person even beside the spring, overuses more resources required or ordered to accomplish a task such as ablution, this kind of overuse of resources, power, force and attention without justifying the necessity is a kind of wastage, even if there is no question of overconsumption or wastage, as making ablution from the water of a stream. The key point concluded from citations with all different understandings and advice, is the fact that: distribution of goods/money or words, or knowledge or wisdom or resources or powers and forces or allocating resources to self (Nafs) without consideration of divine commandments and beyond the limits of devotion is wastage, whatever it could be. In the meantime, if all of these actions are made with attention to divine orders and guidance are verified as the economy (moderation), whatever the action would be. This is why it is narrated if one gives all he has to feed a true real believer; it is worthy and will not be wastage. Those who over-consume or waste contrary to the divine commandments and neglect the divine orders for giving and distributing charity; are brothers of Satan because if the charity is not ordered by God, it is commanded by Satan and Satan is always tending ambuscade to believers and deems his inadvertence. As soon takes control of his wisdom and rules him, the way he rules his devils. "Satan is ungrateful to his lord" refers to the reason because Satan is ungrateful and wastes (resources) denying the divine orders of his Lord, so one refusing the divine rules to avoid the wastage is a brother (confrere) of Satan." The Holy Quran in several verses, sanction wastage as consuming more than needs and the following verses are some of those prohibiting wastage: $(6: 14 \mathrm{I})^{23}$ : "He brings forth gardens, trellised and un-trellised, palm-trees and crops, with different fruits, and the olive and pomegranates alike and unlike, when it bears fruit eat of it and pay what is due (the Zakat) of it upon the harvest day, but do not be wasteful; he does not like the wasteful." In $(7: 3 \mathrm{I})^{24}$ : "Eat and drink, and do not waste. He does not like the wasteful." $(25: 67)^{25}$ : "Those when spend are neither wasteful nor miserly, between that is a just stand". (26:I5I-I52) $)^{26}$ : Do not obey the order of the wasteful who corrupt in the earth, and do not reform". In $(20: 8 \mathrm{I})^{27}$ : "Eat of the good things with which we have provided you and do not transgress therein lest my anger should fall upon you, and upon whosoever, my anger falls has assuredly fallen". The same exegesis $^{28}$ comments the revolt (transgression) in this verse: transgressed means passed limits of moderation and fell into blasphemy, and this became predominant on him and exaggerated in sins and oppression. And all the meanings return to revolting to obey (transgressing) the internal and external wisdom. And the meaning of do not transgress is: from what we have provided to you to consume do not transgress the limits God has drawn, including for subjects such as; the quantity of eating or earning the meal, rules of eating and its extravagancies and accessories attached, and thanking the giver according to the gift or meal offered, or variety of meal or excess of eating, or feeding one with a food one does not deserve, neither without attention to God whereas eating (consumption) is drawn into attention but concerns whatever is provided by God for consumption."

\section{Squandering and sustainable development}

Tabzir in current economic terms is called "overconsumption" and in popular language is called "extravagance". This concept, from the consumption point of view at the macroeconomic level, is significant from the comparative dimension among countries. This is in spite of equality of density of population in different regions; per-capita consumption varies from country to country. For example, China is comparable with the United States of America from the land measure, but per-capita energy consumption in the USA is 9 times as much as China. In other words, in spite of more population of China, her energy

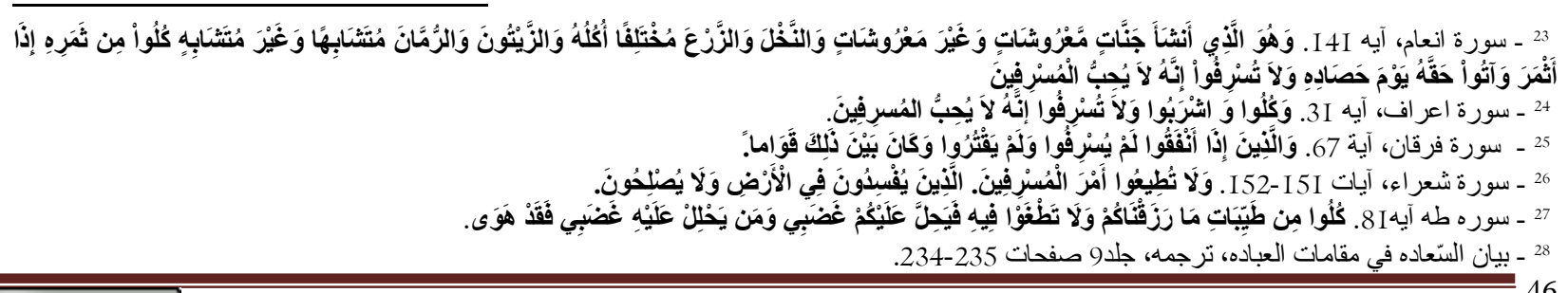


consumption is half of the USA. Overconsumption of energy is one of the important basic problems at national and global levels from heating and other points of view, and the example offered here shows that overconsumption at present global conditions is regarded as a kind of injustice about others rights. For example, energy overconsumption in the USA has helped to heat more the earth, which has created losses to other people of this planet.

Cases such as consumption wastes, conspicuous consumption, keeping up with Jones consumption and other similar cases are considered as overconsumption, which is classified as squandering. These cases are so vast that some of the international texts have also considered illumination and luminescence as overconsumption.

From the sustainable development point of view, overconsumption decreases the carrying capacity of the earth and practically empties the resources and gradually lowers down the level of environment and ecological health. This is in addition to the bad effects of pollution caused by the production and consumption of goods and commodities. The State of the world report ${ }^{29}$ makes it clear that: the ecological capacity of the world is not enough for excessive wishes of China, India, Japan, and America. For example, America has less than $\% 5$ of the world population, but produces $\% 25$ of world $\mathrm{CO}^{30}$ and use $\% 25$ of the world resources $^{31}$. In spite of having $\% 3$ of the world discovered oil resources ${ }^{32}$, America spends $\% 26$ of the world energy ${ }^{33}$ and produces $\% 30$ of the world spoils and wastes ${ }^{34}$. According to researches, the effects of this country on the environment are 250 times more than people of African Sahara ${ }^{35}$. If China and India reach the American level in 2030, they will need the whole planet to satisfy their needs.

From human being life indices point of view, resources needed are higher than resources regarding animals or plants or others. In Five Capital Model ${ }^{36}$ classification, 5 kinds of capital have been considered: natural capital, social capital, human being capital, industrial capital, and financial capital. Squandering debate covers all these capitals and as over-use of these capitals leads to the decrease of carrying capacity of living space of human being in Five Capital Model, in ethic economics also this overconsumption is regarded disagreeable.

In the Holy Quran the verses such as: $21: 9)^{37}$ "then we were true to the promise, we saved them together with those whom we willed, and destroyed the transgressors" and (40:28) "Allah does not guide the lying squanderer" or (I0:I2) "In this way, the deeds of squanders were nice at their opinion" or $(40: 43)^{40}$ "there is no doubt that the squanders are the inhabitants of the fire", and (26:I5I-I52) ${ }^{41}$ : "do not obey the order of the squanders who corrupt in the earth, and do not reform", and (6:I4I):" "He does not like the squanders" and (7:3I): "children of Adam, take your adornment at every place of prayer. Eat and drink, and do not waste. He does not like the squanders". These verses all show how God prohibits overconsumption (transgressing the limits) and squandering.

Generally, in relation to environmental protection the following verse and its exegesis are interesting: (2:205) "No sooner does he leave than he hastens about the earth to corrupt there and destroys crops and cattle. Allah does not like corruption". This means that destroying farms and farm animals are considered as corruption, and God does not like such actions. Destroying farms and animals both directly and via destroying the ecosystem and environment by polluting the environment and making

29 - State of the world 2006, World Watch Institute, II January 2006.

${ }^{30}$ - Global Warming.

${ }^{31}$ - Illinois Recycling Association Recycling Facts.

32 - SEI: Energy Consumption.

${ }^{33}$ - NRDS: Reducing U.S. oil dependence.

${ }^{34}$ - Waste Watcher.

35 - Consumption industrialized, commercialized dehumanized and deadly. And also: US population reaches 300 million, heading for 400 million; no cause for celebration, 4 October 2006.

36 - Five capitals models of sustainable development, Forum for the Future.

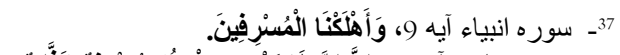

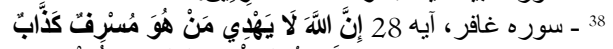

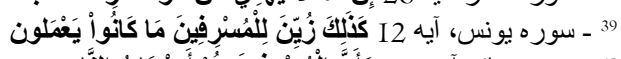

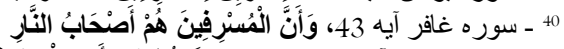

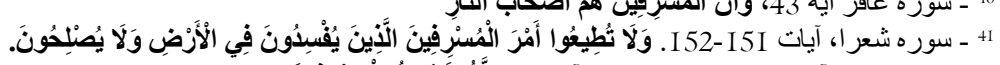
42

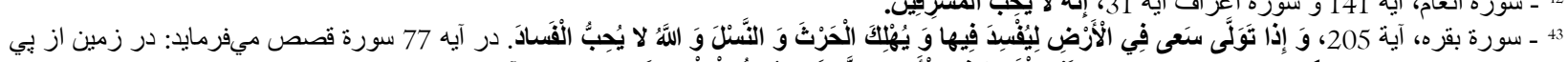

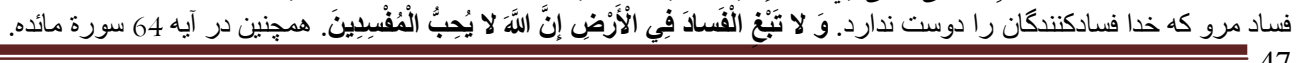


disequilibrium in the ecosystem all are cases of corruption. In the above verse, the farms or farm animals have not been specified to Muslims or believers, and by using the word "earth", all of them around the world have been considered. This approach confronts the Muslim peoples and governments with this class of commandments that have not right to corrupt wherever on the earth. Corruption in the earth from the point of view of the said verse includes many activities that destroy the environment, including plants, animals, and human beings. Generalization to human being compromises those activities that corrupt in the earth via production and trade of harmful materials and chemical poisons to destroy peoples and destroying farms and animals to hurt the others, weapons for attack and weapons of mass destruction, burial of nuclear wastes in poor countries and colluding with agents and their leaders, production, consumption, export and import of any raw or intermediate materials that causes corruption in livestock and humans and harmful to them and other similar cases all are included in this debate.

The am verse is commented as follows by the exegesis of mystics as ${ }^{44}:$ "when he leaves, means when he turns back on you or a responsible assignee of you for a task, whatever the task is including material or responsibility to people. He will accelerate traveling on earth, or the ground of his spirit or myth of prophets and their successors to make corruption on earth and corruption is the fact of devaluating or changing a thing from its perfect place, it is placed into, or impeach that thing reaches its perfection. The insistence comes from the fact that hypocrites declare to be reformers (peacemakers). "When it is said to them, do not corrupt in the land; they reply: we are just reformers, but it is they who are the evildoers, though they do not sense it" ${ }^{45}$ shows they will destroy the fundamentals and fruits. The fruit is the result of what people implant from any type ever to be implanted by man or grow from the earth itself; and the generation (child) of humankind or other creatures ..."

\section{Overconsumption and sustainable production}

Although overconsumption is related to consumption, but regarding that production of goods provides chain products of intermediate goods which are used in the process of production of other goods, we better refer to squandering in production.

A great portion of sustainable production is involved in industrial ecology. That is to say; industrial ecology is a scientific multidisciplinary background which is concentrated on a sustainable combination of environment, economy, and technology. By industrial term in industrial ecology, we don't mean industrial centers, but we mean how people use natural resources in the production process. Basically, industrial ecology is looking for changing industrial processes from linear to closed circular systems. In linear systems, capital and resources will finally turn into spoils and wastes. But in circular systems, wastes are recycled as factors of production in the production process. In other words, industrial ecology is considered as a part of an ecosystem. This view was first expressed by Robert Frosch, Nicholas E. Gallopoulos in 1989 ${ }^{46}$. Their doctrine is: why industrial systems should not act as an ecosystem in which the wastes of an industry become the resources of another industry? This process will cause the consumption of raw material in producing pollution and waste decline in the production process. This view, which is important for increasing the carrying capacity of the earth, has gained the attention of many environmental researchers.

Another related subject is clean technology and concerning regulations, which in a way by various law enactments prevents the expansion of technologies with more bad effects in comparison to other production technologies. Although this subject is at its preliminary stages but will create a good background for the future.

Cleaner production is also one of the subjects related to squandering in production. This topic practically tries to maximize production by minimizing wastes and emission of gases of the production process ${ }^{47}$. The improvement of organization and technology of production will ease better solutions. The discussions of clean production in the fields of documenting consumption of materials and energy and..., using controlling and monitoring systems and producing indicators, replacing raw materials and auxiliary materials, increase of useable life of auxiliary materials and vaporizable liquids, improvement of

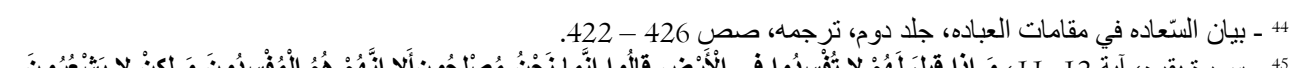

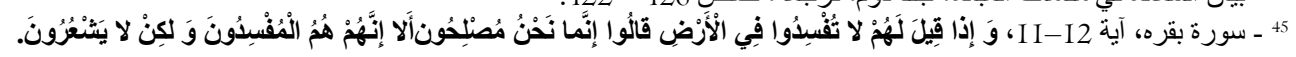
${ }^{46}$ - Robert Frosch, Nicholas E. Gallopoulos, (I989), Strategies for manufacturing, Scientific American, 261 : pp I44-I52.

${ }^{47}$ - Yacoub, Ali, Johannes Fresner (2006) Half is enough, an introduction to cleaner production, Beirut, Lebanon, LCPC Press. 
automation and controlling, recycling spoils and wastes and less-waste producing processes are included in the debates concerning clean production ${ }^{48}$.

\section{Overconsumption and public international law}

From this view, overconsumption is not only disagreeable, but also can be entered in the definitional domain of crimes. This is because over-consumer endangers other's interests to obtain his own interests; therefore, it should be principally defined as a crime. Accordingly, God has clearly mentioned in the verses cited above, that He does not like squanderers and considers them as Satin brothers because Satin is the symbol of opposition to human being and this brotherhood means that squanderer is the enemy of the human being. Certainly, crime is not a fixed rule with unchangeable meaning, and it is not considered crime before being legislated by criminal law. In sociologists' viewpoints, crime is an action which is against the society interests, whether is considered by lawmakers or not ${ }^{49}$. Therefore, in law philosophy, in the definition of law it has been said that it is a regulation governing people living in the society and if people live alone and out of society, they have no obligations and rights. The difference between law and ethics is that ethics are regarded and judged by people themselves, but in law point of view, goodness and badness are studied by the relationship with others ${ }^{50}$. Accordingly, in Islamic law, "the public need rule" has been described which is the public necessity which is a need that may not be at emergency level but since it is in the wellbeing of people, it is respected, and according to Shariah it is considered as law ${ }^{51}$. The rule of "No Loss", which is a rational rule is also emphasizing the same thing, and intellect acknowledges it. On the other hands, the debate of "prohibition of bad" and its relations to rational obligations and also "expediency" from social dimension, all can be commentated and deducted in the framework of the badness of overconsumption. The purpose of explaining these subjects is that humankind should replace overconsumption from individual dimension into social and global dimensions so that the action of over-consumer would not harm others' life. Certainly, many studies should be carried out for the replacement of this view which is more than the subject of this paper and we end this subject by explaining that in defining crime, we are not considering a narrow definition in relation to crime, offense or fault, but we consider a general meaning which is any harmful action for others and fighting with that does not mean legal encountering with criminals, but it is by levying special taxes on over-consumer and squanderers and encouragements for parsimony or substituting resources and so on which are explained in detail in environmental economics texts. Partial international activities have been carried out in this regard including Kyoto Protocol for controlling greenhouse gasses and heating of the earth, and Europe also has conducted Emission Trade Scheme (ETS) in this direction to limit CO2 production ${ }^{52}$.

\section{Conclusion}

Ethic economics is a new name for old value-debates in economics which analyzes economic behavior by considering ethics. Tabzir with the meaning of wasting properties is forbidden in holly Quran and is referred to as overconsumption and waste. This subject has special importance from comparative dimension among countries so that overconsumption is considered as aggression to others' rights at present world conditions, and from this view, squandering is in the realm of crimes.

From a sustainable development point of view, overconsumption decreases the carrying capacity of the earth planet and also increases pollution, and bad effects resulted from the production of goods and services. Sustainable development is a model for using and consuming resources to obtain human being needs while preserving the natural environment so that to safeguard human needs in the future. The emphasis of sustainable development on the supply side is on the methods of improving the environmental performance of main economic sectors, and sustainable consumption emphasizes on the methods of obtaining requirements in a way which do not decrease the carrying capacity of the earth. This concept of consumption requires optimizing consumption by preserving the quality of resources and environment along the time. Industrial ecology is concentrated on the sustainable combination of environment, economy, and technology, and it means the method of using natural resources in the production process and changing the linear production processes to closed cycling processes. In linear systems, resources and capital finally end in the garbage, but in cycling methods, garbage is recycled and used as a factor of

\footnotetext{
48 - Many other instances are related to this subject whom includes the subject of investment such as construction design for using sunshine energy and prevention of leaking energy used for air-conditioning which we will not go through here.

49 - See: Public punishment jurisprudence. Motamed, Mohammad Ali, Tehran University Publication, Vol. I, P. I25, 1973.

${ }^{50}$ - See: The philosophy of law. Katouzian, Naser. Publication Company Ltd,, Vol. I, pp. 540-54I, 1998.

${ }^{51}$ - See: Legal schools of thoughts in Islam. Langaroudi, Mohammad Jafar. Gange Danesh publications, p. I30, 1991.

52 - http://bidabad.com/doc/mohitezist-cement.pdf
} 
production. This view is very important in increasing the carrying capacity of the earth. Clean technology and cleaner production are also related to production squandering debate.

\section{Policy recommendation}

Sustainable development concerns the quality and quantity of human life. But individual countries' decisions are not very effective in implementing sustainable development goals, and we should collect attention of world specialists and policymakers and propaganda on blamefulness of squandering and persuade them to decide on directive instructions and punishing measures for this phenomenon. Therefore, at the national level, indicating this subject and transferring this culture and creating necessary background can be a good starting. Regarding the fact that one side of this discussion is in the domain of ethics and is one of the old value debates in economics and has been put forward by various religions in different ways, we can use this background and blame overconsumption and waste, so that in the next steps, by putting forward this subject at related international organizations and holding international conventions, pass official laws and regulations to restrict this phenomenon.

\section{References}

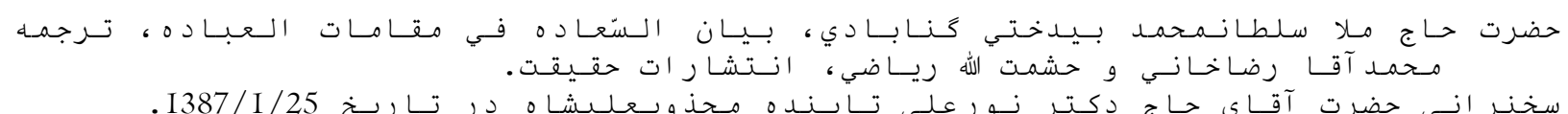
http://mazaresoltani.net/download/mp3/87/87-0I-25-sobhe-eshanbeh-aghl.mp3

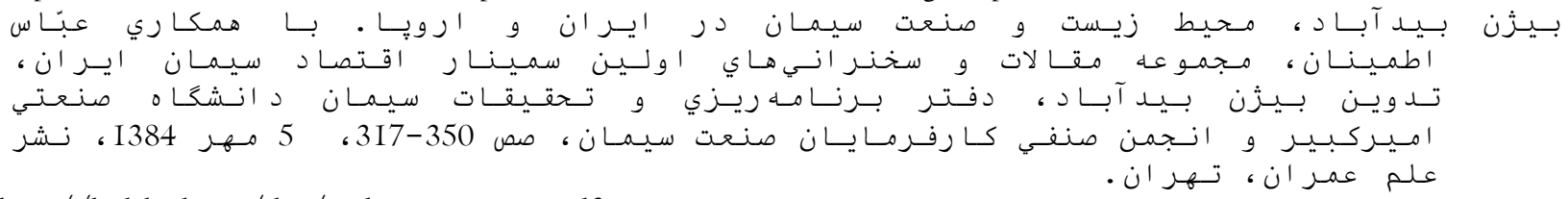

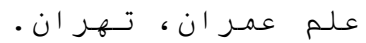

http://bidabad.com/doc/mohitezist-cement.pdf

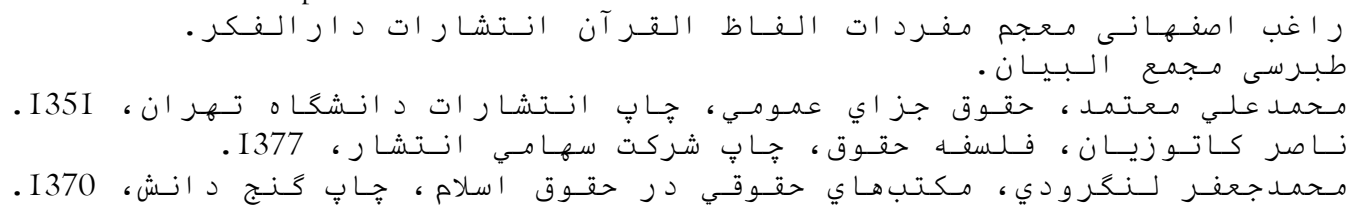

State of the world 2006, World Watch Institute, I I January 2006.

Illinois Recycling Association Recycling Facts.

NRDS: Reducing U.S. oil dependence

SEI: Energy Consumption

Waste Watcher

Consumption industrialized, commercialized dehumanized and deadly.

US population reaches 300 million, heading for 400 million; no cause for celebration, 4 October 2006.

Five capitals models of sustainable development, Forum for the Future.

Report of the world commission on environment and development, United Nations General Assembly Resolution 42/I87, II

December 1987.

Word summit outcome document, World Health Organization, I September 2005.

The Universal Declaration on Cultural Diversity, UNESCO, 2001.

Hasna, A.M., 2007, Dimensions of sustainability, Journal of Engineering for Sustainable Development: Energy Environment and Health 2 (I):47-57.

United Nations Division for Sustainable Development. Documents: Sustainable Development Issues. Retrieved 2007-05-I2.

Temple (1992) What is sustainable development?

Sayre, N.F.2008, The genesis history, and limits of carrying capacity, Annals of the Association of American Geographers 98 (I), pp.I20-I34.

Thomas Malthus, (1798). An essay on the principle of population.

The Club of Rome, Limits to growth (1972).

Paul R. Ehrlich (1968). Population bomb.

Ester Boserup (1965), The conditions of agricultural growth, Allen Unwin. Revised and reprinted in population and technology, Blackwell 1980. 
Robert Frosch, Nicholas E. Gallopoulos (1989), Strategies for manufacturing, Scientific American, 26 I: pp I44-I52.

Yacoub, Ali, Johannes Fresner (2006) Half is enough, an introduction to cleaner production, Beirut, Lebanon, LCPC Press. http://www.iisd.org/susprod/principles.htm

Symposium: Sustainable Consumption. Oslo, Norway; 19-20 January 1994.

Edwin G. Falkman, Waste Management International. Sustainable Production and Consumption: A Business Perspective. WBCSD, n.d.

Nick Robins and Sarah Roberts, Changing Consumption and Production Patterns: Unlocking Trade Opportunities. International Institute for Environment and Development and UN Department of Policy Coordination and Sustainable Development, 1997.

Dr. Emil Salim, The challenge of sustainable consumption, as seen from the South. In Symposium: Sustainable Consumption. Oslo, Norway; 19-20 January 1994.

\section{Copyrights}

Copyright for this article is retained by the author(s), with first publication rights granted to the journal. This is an open-access article distributed under the terms and conditions of the Creative Commons Attribution license (http://creativecommons.org/licenses/by/4.0/). 